\title{
Zooplankton diversity and macrophyte biometry in shallow water bodies of various trophic state
}

\author{
Natalia Kuczyńska-Kippen • Tomasz Joniak
}

Received: 18 September 2015/Revised: 12 November 2015/Accepted: 17 November 2015/Published online: 1 December 2015 (C) The Author(s) 2015. This article is published with open access at Springerlink.com

\begin{abstract}
In order to determine whether using indicators of zooplankton diversity and macrophyte parameters (density and biomass) could be a useful tool for diagnosing the water quality of ponds we hypothesised that in various trophic types of shallow water bodies parameters of a macrophyte habitat will reflect zooplankton diversity. Thus, 439 stations (open water, helophytes, elodeids) were studied among 274 pastoral ponds (mid-west Poland). In each trophic state of waters a key predictor of zooplankton diversity was biomass of macrophytes attributed to a variety of ecological types or various species of macrophytes. A shift from the high importance of elodeids (e.g. Myriophyllum, Ceratophyllum demersum) in structuring zooplankton diversity in mesotrophic waters to helophytes (Typha angustifolia, Phragmites australis, Schoenoplectus lacustris) in hypereutrophic ponds was recorded. Hypereutrophy proved to be extremely unfavourable for zooplankton, as reflected in its lowest diversity; rotifers reached their optimum in eutrophy and crustaceans in mesotrophy. Adverse environmental conditions in hypereutrophic waters caused the
\end{abstract}

Guest editors: Pierluigi Viaroli, Marco Bartoli \& Jan Vymazal / Wetlands Biodiversity and Processes: Tools for Management and Conservation

N. Kuczyńska-Kippen $(\bowtie) \cdot$ T. Joniak

Department of Water Protection, Faculty of Biology,

Adam Mickiewicz University, Umultowska 89,

61-614 Poznan, Poland

e-mail: kippen@hot.pl elimination of macrophyte-dominated refuges, thereby lowering the macrophyte-site share, which ranged from $47 \%$ in eutrophy, $40 \%$ in mesotrophy to only $20 \%$ in hypereutrophy. Therefore, we assume that zooplankton diversity and macrophyte occurrence can be used for quality assessment of small water bodies.

Keywords Shallow ponds - Rotifer and crustacean diversity · Trophic status - Aquatic plant biomass · Environmental predictors

\section{Introduction}

Ponds, which are considered to be small ecological complexes, form model systems for studying various ecological relationships as well as evolutionary biology. The necessity for environmental monitoring of global transformation relating e.g. to climate warming or human-induced eutrophication of waters (Céréghino et al., 2014) has recently arisen and ponds are perfect objects for such analyses. In small water bodies, where macrophyte-dominated zones often prevail and occasionally the whole water column is fully overgrown by macrophytes with no typical open water areas, a development of new methods for water quality assessment is required, especially as methods designed for large aquatic ecosystems such as lakes may be unsuitable. Therefore, we directed our analyses towards the elaboration of simple methods to 
assess water conditions for small aquatic ecosystems. This is very important in the light of recent observations made by many researchers who ascertain that there is a worldwide phenomenon concerning not only human-induced deterioration of water quality but also the loss of pond biodiversity caused by human activity (e.g. De Marco et al., 2014).

Aquatic vegetation, which shapes the structural environment for a variety of invertebrates in many systems (Stansfield et al., 1997; Cazzanelli et al., 2008), is often of primary importance. This is why, even if a pond is of a small area and depth, it is crucial to carry out research in various microhabitats which vary in their spatial complexity. The present study was therefore undertaken within three distinct types of habitats: two vegetated sites (elodeids and helophytes) and another in the open water area. Elodeids are known to create habitats that are complex and provide the inhabiting organisms with a variety of ecological niches (Tolonen et al., 2003; Kuczyńska-Kippen \& Nagengast, 2006). Contrary to elodeids, helophytes create on average habitats of a much lower level of spatial and morphological entanglement (KuczyńskaKippen \& Nagengast, 2006). Habitat complexity can be expressed by the biometric features of a macrophyte habitat and measured as the length or biomass of macrophyte stems in a certain unit of water (Nagengast \& Kuczyńska-Kippen, 2015). The level of such complexity of a plant stand greatly depends on the ecological group that a macrophyte represents.

The varying architecture of macrophytes plays a multiplicity of ecological roles. They may create refuge conditions for zooplankton. In ponds with fish presence, abundant communities of pelagic zooplankters, especially larger-bodied crustaceans, despite their ecological requirements, will be found among patches of macrophytes during the daytime when fish are most active (Wojtal et al., 2003). At the same time plant habitat, due to its highly complex structure connected with an increase in the fractal variation of a plant patch (McAbendroth et al., 2005; Dibble \& Thomaz, 2006), may support the development of a variety of periphytic planktonic organisms, thus favouring the development of zooplankton species of littoral origin (Duggan, 2001). Therefore, macrophyte build reflected in the plant density or biomass, known as plant architecture, is of significant importance for the inhabiting zooplankters. The higher the habitat complexity, the greater the diversity of both rotifers and crustaceans, both in large aquatic ecosystems such as lakes and in small water bodies.

Despite our knowledge of the key role played by macrophytes as habitats for various organisms, our recognition of macrophytes as indicators of water quality is still limited (Kłosowski \& Jabłońska, 2009). The trophic state of water may also be fundamental for the diversity of many other aquatic organisms (De Marco et al., 2014), including zooplankton (Barnett \& Beisner, 2007; Habelman \& Haldna 2014). This is why zooplankton diversity features were examined not only in as regards macrophyte architecture but also with respect to different trophic levels of water and physico-chemical parameters. It has also been shown (Malthus et al., 1990, Roman et al., 2001, LycheSolheim et al., 2013) that trophic conditions of water may be responsible for the occurrence of particular plant species and thus presumably also have an impact on the level of heterogeneity of a vegetated bed. Because the species diversity of organisms, besides other community factors such as abundance or trophic groups (Zervoudaki et al., 2009; Obertegger \& Manca, 2011), may undergo a contrasting response to trophic conditions and thus be a good indicator of the water quality we hypothesised that the biometric features of a macrophyte habitat will significantly influence zooplankton diversity, irrespective of certain macrophyte species predominating in various trophic types of shallow water bodies. Therefore, the primary object of our study was to determine whether using indicators of zooplankton diversity and macrophyte biometric features would easily diagnose trophic conditions of water. Hence, we searched for the characteristics of biotic components within trophic groups of ponds.

\section{Materials and methods}

\section{Study site}

The examination including 274 shallow water bodies was carried out during the optimum summer season in the years 2004-2013. In order to avoid the diurnal variation in both abiotic and biotic features all performed field analyses and samplings were performed at the same time-around midday. The study area was located within the following physico-geographical macroregions: Lubusz Lakeland, Greater Poland Lakeland, Southern Greater Poland Lowland and the Warta- 
Oder Glacial Valley (Kondracki, 2001) and four large districts in central and western Poland in the Provinces of Kujawy-Pomerania, Lower Silesia, Lubuskie and Wielkopolskie covering over $80,000 \mathrm{~km}^{2}$ (geographical coordinates of study area-in the north: $53^{\circ} 10^{\prime} 18^{\prime \prime} \mathrm{N}$, $16^{\circ} 46^{\prime} 56^{\prime \prime} \mathrm{E}$, in the south: $51^{\circ} 03^{\prime} 12^{\prime \prime} \mathrm{N}, 17^{\circ} 04^{\prime} 53^{\prime \prime} \mathrm{E}$, in the east: $52^{\circ} 21^{\prime} 21^{\prime \prime} \mathrm{N}, 17^{\circ} 52^{\prime} 17^{\prime \prime} \mathrm{E}$, in the west: $\left.51^{\circ} 56^{\prime} 18^{\prime \prime} \mathrm{N}, 15^{\circ} 30^{\prime} 24^{\prime \prime} \mathrm{E}\right)$. All the studied ponds were situated within an agricultural landscape: fields, pastures and meadows or within residential and rural settlements. They reached depths of between 0.1 and $5.0 \mathrm{~m}$ and had surface areas of between 0.001 and 3.42 ha. They differed with respect to fish presence (in $25 \%$ of the water bodies fish were absent) and to their origin (post-glacial ponds, oxbows and artificial ponds). The presence of fish may have a decisive effect on the structure of zooplankton assemblages and it can partially or even completely mask the effect of other environmental factors. This is why we have decided to exclude fish from our analysis so as to obtain a clear relationship between zooplankton with respect to trophic conditions and macrophyte biometry.

Sampling and laboratory analysis

Altogether 439 stations were studied, including: the open water zone (total number 274 of the sampling stations), sites located within helophytes (59) and elodeids (106). At each station depth of water and physical-chemical parameters were measured; biological material (macrophytes, zooplankton) as well as water for chemical laboratory analysis were sampled.

There were five species of helophytes: Phragmites australis (Cav.) Trin. ex Steud (Phr), Schoenoplectus lacustris (L.) Palla (Sch), Sparganium erectum L. em. Rchb. (Spr), Typha angustifolia L. (Tan), T. latifolia L. (Tla) and eight species of elodeids: Ceratophyllum demersum L. (Cde), C. submersum L. (Csu), Chara hispida L., Ch. tomentosa L., Myriophyllum spicatum L., M. verticillatum L., Potamogeton pectinatus L., P. pusillus L. Because some plant species are of a similar morphological build they were placed in one group: Chara hispida and Ch. tomentosa were joined together (Cha) as well as Myriophyllum spicatum and M. verticillatum (Myr) and also Potamogeton pectinatus and P. pusillus (Pot). At each macrophyte site the plant matter was cut (in triplicate) from a volume of $0.25 \times 0.25 \times 0.25 \mathrm{~m}$, measured, then dried and weighed in order to characterise the biometric features of a macrophyte habitat, understood as the stem density - length and dry plant biomass in 11 of pond water. Macrophyte biometry was calculated so as to provide data on the spatial and morphological complexity of a particular plant patch.

Zooplankton was sampled in triplicate (total $n=1335$ ) from randomly chosen places within each single site using a plexiglass core sampler (Schriver et al., 1995), going vertically through the vegetated stand. In the case of the open water area, a calibrated vessel of a volume of 51 was applied. 201 samples were collected from the open water zone, while $10 \mathrm{l}$ samples were taken from detritus-rich sites located within macrophytes. In order to avoid the effect of the vertical changeability in the abiotic and biotic features and to obtain comparable material, all the samples were collected from the surface layer of water. The obtained samples were passed through a $45-\mu \mathrm{m}$ net and fixed with $4 \%$ formalin. For the final calculations, mean values of zooplankton densities were applied, while for the taxonomic diversity both the mean and total number of species were taken into consideration. The whole sample was checked for the purpose of taxonomic identification of zooplankton to obtain a high level of taxonomic resolution. Representatives of crustaceans were identified into species. Rotifers were identified to the level of species in most cases and to genus for a restricted amount of soft-bodied taxa, e.g. representatives of the family Notommatidae, which become contracted in the process of sample preservation. Counting of zooplankton was performed in accordance with advisable techniques recommended for this group of organisms (Mack et al., 2012).

In the subsurface layer of each open water station as well as among macrophyte sites, parameters such as water temperature, oxygen saturation (OS), $\mathrm{pH}$ and conductivity (EC) were measured (Hanna Instruments HI-991300, HI-9146). Secchi depth visibility (SDV) with white disc (diameter $30 \mathrm{~cm}$ ) was measured only in open water when the depth of water was sufficient to measure. In other cases the visibility parameter was not measured. Sampling of water for chemical analyses preceded the collection of water for zooplankton analyses and measurements of the plant habitat. Each sample was taken with the utmost care so as to limit the movement of water over the bottom and/or within the plant bed. Water for chemical analyses was placed into polyethylene containers without conservation. Pretreatment filtration of the sample through a cotton 
Table 1 Statistical comparison of mean values $( \pm \mathrm{SD})$ of zooplankton diversity features, macrophytes and physico-chemical parameters in groups of ponds distinguished on the basis of trophic state (meso mesotrophic, eutr eutrophic, hyper hypereutrophic)

\begin{tabular}{|c|c|c|c|c|c|c|}
\hline \multirow[t]{2}{*}{ Parameter } & \multicolumn{3}{|l|}{ Trophic state } & \multirow[t]{2}{*}{ Mean rank difference } & \multirow[t]{2}{*}{$P$} & \multirow[t]{2}{*}{ Sense } \\
\hline & Meso & Eutr & Hyper & & & \\
\hline $\mathrm{TSI}_{\mathrm{av}}$ & $47 \pm 4$ & $63 \pm 5$ & $78 \pm 7$ & & & \\
\hline Meso versus eutr & & & & -132.44 & $* * *$ & Meso $<$ eutr \\
\hline Meso versus hyper & & & & -333.91 & $* * *$ & Meso $<$ hyper \\
\hline Eutr versus hyper & & & & -201.48 & $* * *$ & Eutr $<$ hyper \\
\hline Area (ha) & $0.54 \pm 0.51$ & $0.54 \pm 0.58$ & $0.34 \pm 0.56$ & & & \\
\hline Meso versus eutr & & & & -3.103 & ns & \\
\hline Meso versus hyper & & & & 70.470 & $*$ & Meso $>$ hyper \\
\hline Eutr versus hyper & & & & 73.573 & $* * *$ & Eutr $>$ hyper \\
\hline Depth (m) & $2.0 \pm 1.5$ & $1.6 \pm 1.0$ & $0.9 \pm 0.7$ & & & \\
\hline Meso versus eutr & & & & 48.296 & ns & \\
\hline Meso versus hyper & & & & 138.84 & $* * *$ & Meso $>$ hyper \\
\hline Eutr versus hyper & & & & 90.539 & $* * *$ & Eutr $>$ hyper \\
\hline SDV (m) & $1.4 \pm 1.2$ & $0.9 \pm 0.5$ & $0.4 \pm 0.3$ & & & \\
\hline Meso versus eutr & & & & 9.485 & ns & \\
\hline Meso versus hyper & & & & 91.621 & $* * *$ & Meso $>$ hyper \\
\hline Eutr versus hyper & & & & 82.136 & $* * *$ & Eutr $>$ hyper \\
\hline $\mathrm{pH}$ & 8.0 & 8.0 & 8.3 & & & \\
\hline Meso versus eutr & & & & -1.068 & ns & \\
\hline Meso versus hyper & & & & -68.782 & $*$ & Meso $<$ hyper \\
\hline Eutr versus hyper & & & & -67.714 & $* * *$ & Eutr $<$ hyper \\
\hline OS $(\%)$ & $100 \pm 30$ & $85 \pm 50$ & $72 \pm 55$ & & & \\
\hline Meso versus eutr & & & & 39.497 & ns & \\
\hline Meso versus hyper & & & & 74.241 & $* *$ & Meso $>$ hyper \\
\hline Eutr versus hyper & & & & 34.744 & $*$ & Eutr $>$ hyper \\
\hline $\mathrm{EC}\left(\mu \mathrm{S} \mathrm{cm}{ }^{-1}\right)$ & $760 \pm 375$ & $750 \pm 355$ & $805 \pm 460$ & & & \\
\hline Meso versus eutr & & & & $\mathrm{n} /$ diff & & \\
\hline Meso versus hyper & & & & $\mathrm{n} /$ diff & & \\
\hline Eutr versus hyper & & & & $\mathrm{n} /$ diff & & \\
\hline $\mathrm{TP}\left(\mathrm{mg} \mathrm{P} 1^{-1}\right)$ & $0.06 \pm 0.07$ & $0.24 \pm 0.45$ & $0.94 \pm 1.07$ & & & \\
\hline Meso versus eutr & & & & -103.63 & $* * *$ & Meso $<$ eutr \\
\hline meso versus hyper & & & & -256.90 & $* * *$ & Meso < hyper \\
\hline Eutr versus hyper & & & & -153.27 & $* * *$ & Eutr $<$ hyper \\
\hline $\mathrm{DIN}\left(\mathrm{mg} \mathrm{N} 1^{-1}\right)$ & $1.1 \pm 1.5$ & $1.5 \pm 1.7$ & $2.4 \pm 2.3$ & & & \\
\hline Meso versus eutr & & & & -67.091 & $*$ & Meso $<$ eutr \\
\hline Meso versus hyper & & & & -158.41 & $* * *$ & Meso < hyper \\
\hline Eutr versus hyper & & & & -91.315 & $* * *$ & Eutr $<$ hyper \\
\hline Chl-a & $6.0 \pm 5.6$ & $25.1 \pm 34.0$ & $77.2 \pm 171.8$ & & & \\
\hline Meso versus eutr & & & & -124.62 & $* * *$ & Meso < eutr \\
\hline Meso versus hyper & & & & -212.13 & $* * *$ & Meso $<$ hyper \\
\hline Eutr versus hyper & & & & -87.514 & $* * *$ & Eutr $<$ hyper \\
\hline EL length $\left(\mathrm{cm} \mathrm{l}^{-1}\right)$ & $40 \pm 26$ & $95 \pm 129$ & $89 \pm 169$ & & & \\
\hline Meso versus eutr & & & & $\mathrm{n} /$ diff & & \\
\hline Meso versus hyper & & & & $\mathrm{n} /$ diff & & \\
\hline
\end{tabular}


Table 1 continued

\begin{tabular}{|c|c|c|c|c|c|c|}
\hline \multirow[t]{2}{*}{ Parameter } & \multicolumn{3}{|l|}{ Trophic state } & \multirow[t]{2}{*}{ Mean rank difference } & \multirow[t]{2}{*}{$P$} & \multirow[t]{2}{*}{ Sense } \\
\hline & Meso & Eutr & Hyper & & & \\
\hline Eutr versus hyper & & & & $\mathrm{n} /$ diff & & \\
\hline EL biomass $\left(\mathrm{g}^{-1}\right)$ & $1.42 \pm 0.7$ & $0.86 \pm 0.5$ & $0.75 \pm 0.4$ & & & \\
\hline Meso versus eutr & & & & 25.834 & $*$ & Meso $>$ eutr \\
\hline Meso versus hyper & & & & 31.849 & $*$ & Meso $>$ hyper \\
\hline Eutr versus hyper & & & & 6.015 & ns & \\
\hline $\mathrm{H}$ length $\left(\mathrm{cm} \mathrm{l}^{-1}\right)$ & $16.1 \pm 6.8$ & $15.9 \pm 11.2$ & $41.5 \pm 55.9$ & & & \\
\hline Meso versus eutr & & & & $\mathrm{n} /$ diff & & \\
\hline Meso versus hyper & & & & $\mathrm{n} /$ diff & & \\
\hline Eutr versus hyper & & & & $\mathrm{n} /$ diff & & \\
\hline $\mathrm{H}$ biomass $\left(\mathrm{g}^{-1}\right)$ & $1.1 \pm 0.4$ & $1.0 \pm 0.5$ & $1.2 \pm 0.5$ & & & \\
\hline Meso versus eutr & & & & $\mathrm{n} / \mathrm{diff}$ & & \\
\hline Meso versus hyper & & & & $\mathrm{n} /$ diff & & \\
\hline Eutr versus hyper & & & & $\mathrm{n} /$ diff & & \\
\hline N Rot & $19 \pm 9$ & $28 \pm 13$ & $21 \pm 11$ & & & \\
\hline Meso versus eutr & & & & -86.878 & $* * *$ & Meso $<$ eutr \\
\hline Meso versus hyper & & & & -21.461 & ns & \\
\hline Eutr versus hyper & & & & 65.418 & $* * *$ & Eutr $>$ hyper \\
\hline Sh Rot & $1.72 \pm 0.64$ & $1.90 \pm 0.69$ & $1.52 \pm 0.67$ & & & \\
\hline Meso versus eutr & & & & -47.195 & ns & \\
\hline Meso versus hyper & & & & 19.734 & ns & \\
\hline Eutr versus hyper & & & & 66.929 & $* * *$ & Eutr $>$ hyper \\
\hline N Clad & $8 \pm 5$ & $7 \pm 5$ & $5 \pm 4$ & & & \\
\hline Meso versus eutr & & & & 18.653 & ns & \\
\hline Meso versus hyper & & & & 76.203 & $* *$ & Meso $>$ hyper \\
\hline Eutr versus hyper & & & & 57.550 & $* * *$ & Eutr $>$ hyper \\
\hline Sh Clad & $1.18 \pm 0.58$ & $1.06 \pm 0.63$ & $0.69 \pm 0.59$ & & & \\
\hline Meso versus eutr & & & & 35.075 & ns & \\
\hline Meso versus hyper & & & & 81.247 & $* * *$ & Meso > hyper \\
\hline Eutr versus hyper & & & & 46.172 & $* * *$ & Eutr $>$ hyper \\
\hline N Cop & $3 \pm 2$ & $3 \pm 2$ & $3 \pm 2$ & & & \\
\hline Meso versus eutr & & & & -10.242 & ns & \\
\hline Meso versus hyper & & & & 24.063 & ns & \\
\hline Eutr versus hyper & & & & 34.304 & $* *$ & Eutr $>$ hyper \\
\hline Sh Cop & $0.65 \pm 0.64$ & $0.62 \pm 0.57$ & $0.47 \pm 0.50$ & & & \\
\hline Meso versus eutr & & & & 35.919 & ns & \\
\hline Meso versus hyper & & & & 60.620 & $* *$ & Meso $>$ hyper \\
\hline Eutr versus hyper & & & & 24.701 & ns & \\
\hline
\end{tabular}

The statistical tests were Dunn's multiple comparison test (significant differences: $* * * P<0.001 ; * * P<0.01 ; * P<0.05 ; n s$ not significant, $n /$ diff not differences). Zooplankton diversity features were: $N$ Rot species number of Rotifera, Sh Rot Shannon index of Rotifera, $N$ Clad species number of Cladocera, Sh Clad Shannon index of Cladocera, N Cop species number of Copepoda, Sh Cop Shannon index of Copepoda); physico-chemical parameters: SDV Secchi disc visibility, $p H, O S$ oxygen saturation, EC electric conductivity, TP total phosphorus, DIN dissolved inorganic nitrogen, $C h l-a$ chlorophyll-a 
filter (several layers of non-sterile cotton gauze placed in a PP funnel) was carried out in the field to separate foreign matter, such as insects, sediment and detritus.

Water samples were analysed in the laboratory to determine: total phosphorus (TP, after persulphate digestion), nitrate nitrogen (with sulphanilic acid), nitrite nitrogen (with 1-Naftylamine) and ammonium (with the Nessler method). Dissolved inorganic nitrogen (DIN) was the sum of nitrate, nitrite and ammonium nitrogen. These analyses were carried out following standard methods as reported in APHA (1998). Chlorophyll- $a$ concentration (corrected for phaeophytin) was measured spectrophotometrically with hot ethanol (PN-ISO 10260).

Trophic status of water was estimated using the Trophic State Index as described by Carlson (1977), where the average values $\left(\mathrm{TSI}_{\mathrm{av}}\right.$ ) of total phosphorus $\left(\mathrm{TSI}_{\mathrm{TP}}\right)$, chlorophyll-a $\left(\mathrm{TSI}_{\mathrm{Chl}}\right)$ and water transparency $\left(\mathrm{TSI}_{\mathrm{SD}}\right)$ were taken into consideration. A range of TSI indices for trophic stages were taken from Carlson \& Simpson (1996). In the case of water stations, $\mathrm{TSI}_{\mathrm{av}}$ was calculated as mean $\mathrm{TSI}_{\mathrm{Chl}}+$ $\mathrm{TSI}_{\mathrm{TP}}+\mathrm{TSI}_{\mathrm{SD}}$ if depth of water was larger than SDV, but when the visibility was equal to the depth of a pond it was calculated with the exclusion of TSI Concerning a great variation of environmental parameters between the open water area and macrophytedominated sites (Joniak et al., 2007), the trophic conditions of the examined ponds were assessed based on the open water measurements, while in all other analyses the results of physical-chemical variables taken from each separate site were taken into consideration.

Data analysis

The Shannon-Weaver index (Margalef, 1957) was used to measure the taxonomic diversity attributed to each pond and station. The Dunn test was performed to determine statistically significant differences in the zooplankton diversity measures, biometric measurements of a macrophyte habitat and environmental factors between the trophic types of water bodies. RDA (redundancy analysis) was used to extract and summarise the variation in the aquatic plants, their biometric features and zooplankton data versus abiotic parameters of water. To identify the effect of the environmental factors on the zooplankton diversity
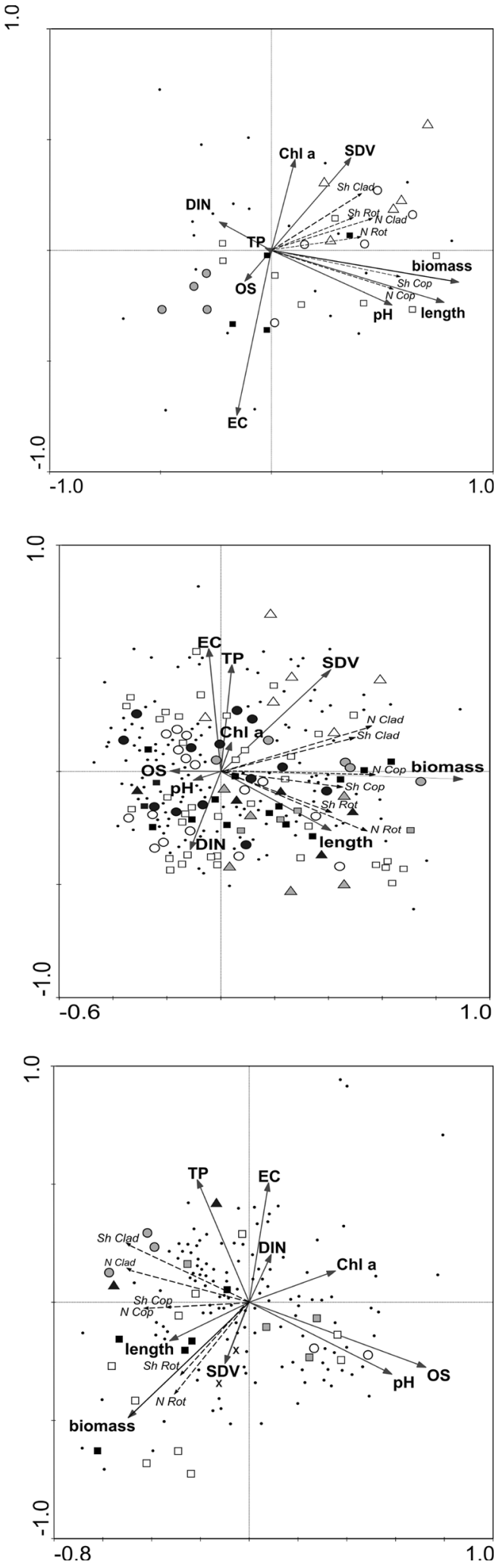
४Fig. 1 Redundancy analysis (RDA) for zooplankton data in aquatic plants and open water (white circle Phr, black circle Tla, grey circle Tan, white triangle $\mathrm{Myr}$, black triangle $\mathrm{Sch}$, grey triangle Cha, white square $\mathrm{Cde}$, black square $\mathrm{Csu}$, grey square Pot, time symbol Spr, bullet water) versus abiotic parameters in mesotrophic ponds (top), eutrophic ponds (middle) and hypereutrophic ponds (bottom). Habitat symbols see Fig. 3

parameters in the three types of ponds distinguished on the basis of trophic conditions of water, automatic forward selection of environmental variables (in RDA analysis) was used in combination with the Monte Carlo permutation test (999 permutations) (Lepš \& Šmilauer, 2003). All the statistical analyses were performed using the R statistical package (R Development Core Team, 20012) and CANOCO ver. 4.5 software (ter Braak \& Šmilauer, 2002).

\section{Results}

Trophic status of water and variability of environmental parameters

Three trophic levels of water bodies were distinguished: 24 mesotrophic ponds TSI $\left._{\mathrm{av}} \geq 39-50\right), 130$ eutrophic ( $>50-70)$ and 120 hypereutrophic $(>70)$. In terms of water surface and depth, ponds representing meso- and eu-trophic state were significantly larger than the hypereutrophic type (Table 1). The chlorophyll and transparency index fell within the range of eutrophy, while the phosphorus index was in hypereutrophy. Slightly alkaline $\mathrm{pH}$, good oxygenation and a moderate level of mineralization $\left(<1000 \mu \mathrm{S} \mathrm{cm}^{-1}\right)$ were among typical features of water chemistry (Table 1). The main quality differences in the trophic groups of ponds resulted from the TP and DIN concentration which were directly proportional to the trophic gradient. Hypereutrophic ponds were overloaded with nitrogen. Differences in the phytoplankton biomass were related to each group of water bodies (Table 1). Maximum concentrations occurred in the hypereutrophic ponds, which indicated favourable conditions for algal development. Variability of chlorophyll concentrations in meso- and eutrophy was low, while in hypereutrophy the standard deviation was a multiple of the mean value. In addition, it should be noted that in $40 \%$ of the studied ponds $(45 \%$ in eu- and hypereutrophy, respectively, $30 \%$ in mesotrophy), the water depth was equal to the visibility of the Secchi disc, which contributed to the exclusion of this parameter from water quality assessment.

Some macrophyte biometric features differed significantly with respect to the trophic conditions of water (Table 1). Biomass of elodeids decreased along with the trophic gradient, while the biomass and length, understood as the stem density, of helophytes was highest in hypereutrophic waters. An important feature of mesotrophic and eutrophic ponds was a large, almost $50 \%$ participation of the macrophytedominated stands out of all the examined sites. In the case of hypereutrophic ponds, the open water area (80\% of the stations) dominated over macrophyte stands (Fig. 1).

Zooplankton and environmental features in trophic stages

All zooplankton diversity indices differed significantly in respect to the trophic state of water. Rotifers were most variable in eutrophic ponds (Fig. 2). Their mean species number was lowest in mesotrophy, while the Shannon-Weaver index was lowest in hypereutrophic waters. Crustaceans appeared to have higher diversity in mesotrophic waters and lower in hypereutrophic ponds (Table 1).

The Monte Carlo permutation test was used with 999 permutations to select significant variables (Table 2). Among the analysed trophic levels, the same number of indicative parameters (5) was detected for eutrophy and hypereutrophy, but only two for mesotrophy. Among parameters important in formation of zooplankton diversity in various trophic types of small water bodies, only biomass of aquatic plants and SDV had a significantly high impact on zooplankton diversity. In higher trophic state water mineralization, TP and oxygen saturation were very important, especially in hypereutrophy (Fig. 1).

RDA showed that in mesotrophic ponds the biomass of macrophytes and water transparency were significant predictors of zooplankton diversity (Fig. 1; Table 2). Diversity of rotifers and cladocerans revealed a similar distribution pattern, while copepods occurred separately. The effect of increased water transparency was particularly pronounced for cladocerans and rotifers. Moreover, $\mathrm{pH}$ increased the diversity of copepods. Nutrients as well 

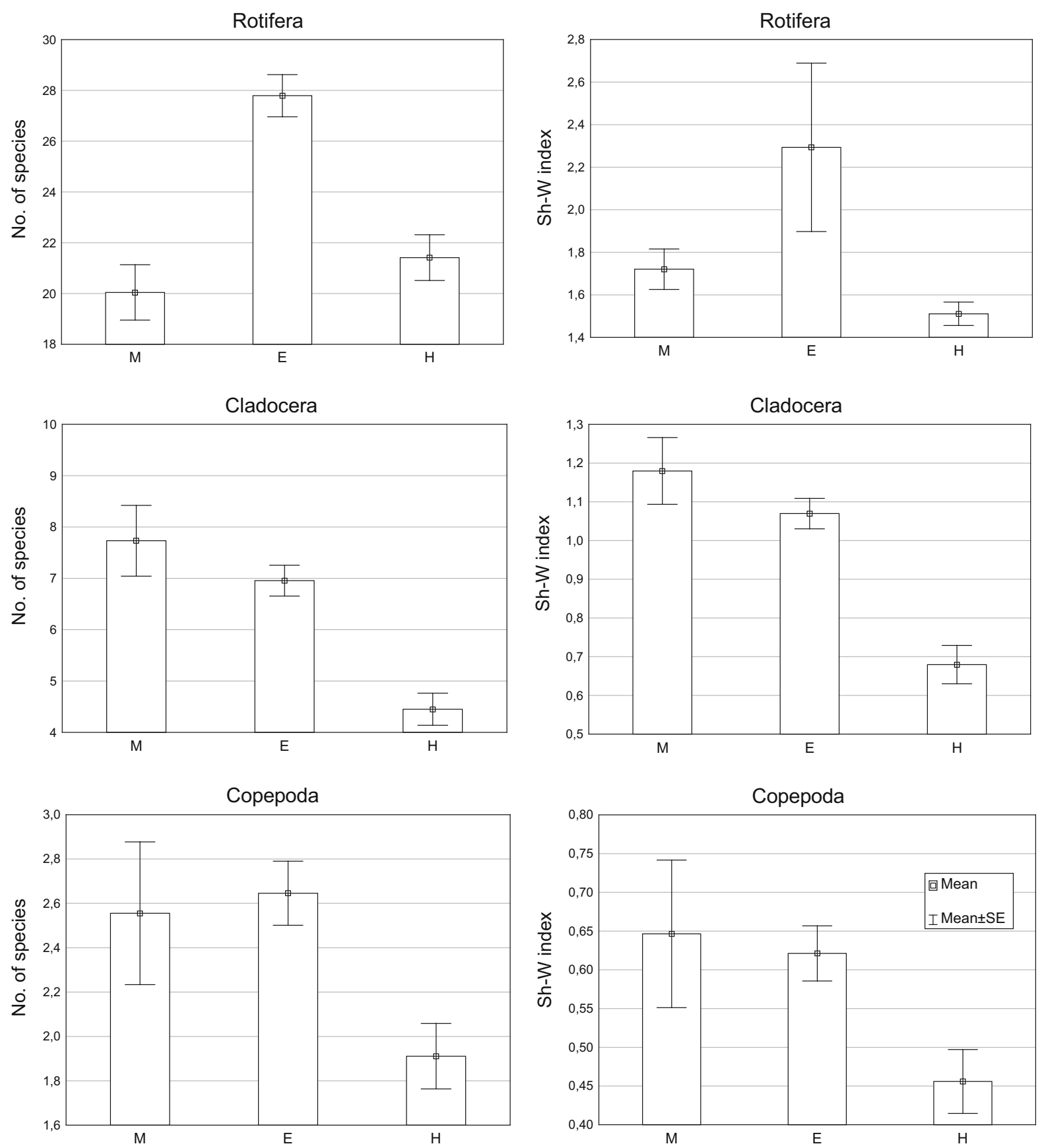

Fig. 2 Comparison of the number of species (left column) and Shannon index values (right column) of zooplankton groups in different trophic states of water ( $M$ mesotrophic, $E$ eutrophic, $H$ hypereutrophic)

as chlorophyll-a concentration had a generally weak impact, with the exception of nitrogen concentration which negatively influenced copepod diversity. Plant biometric features had a powerful effect on the increase of zooplankton diversity. The highest stem length was found for Myriophyllum spp. and Ceratophyllum demersum, while $C$. demersum and Phragmites australis were responsible for obtaining the highest biomass in mesotrophic ponds (Fig. 3A). Rotifer and cladoceran diversity rose along with the 
Table 2 Results of the forward selection of environmental variables (Monte Carlo permutation test in CCA, $P \leq 0.05$ are statistically significant and given in bold) in trophic groups of small water bodies

\begin{tabular}{|c|c|c|c|c|c|c|c|c|c|}
\hline \multirow[t]{3}{*}{ Variable } & \multicolumn{9}{|c|}{ Trophic status of water } \\
\hline & \multicolumn{3}{|c|}{ Mesotrophy } & \multicolumn{3}{|c|}{ Eutrophy } & \multicolumn{3}{|c|}{ Hypereutrophy } \\
\hline & $\lambda$ & $F$ & $P$ & $\lambda$ & $F$ & $P$ & $\lambda$ & $F$ & $P$ \\
\hline Biomass & 0.31 & 19.01 & 0.000 & 0.18 & 55.15 & 0.001 & 0.08 & 15.15 & 0.001 \\
\hline Length & 0.01 & 0.55 & 0.598 & 0.00 & 1.13 & 0.288 & 0.00 & 0.71 & 0.549 \\
\hline SDV & 0.06 & 4.21 & 0.017 & 0.01 & 4.28 & 0.014 & 0.02 & 2.81 & 0.038 \\
\hline $\mathrm{pH}$ & 0.03 & 2.33 & 0.082 & 0.00 & 0.28 & 0.863 & 0.01 & 1.92 & 0.130 \\
\hline OS & 0.02 & 1.47 & 0.199 & 0.02 & 3.38 & 0.040 & 0.14 & 22.58 & 0.001 \\
\hline $\mathrm{EC}$ & 0.02 & 0.93 & 0.383 & 0.02 & 5.83 & 0.004 & 0.03 & 5.51 & 0.005 \\
\hline Chl-a & 0.02 & 1.21 & 0.265 & 0.00 & 0.97 & 0.863 & 0.01 & 1.33 & 0.236 \\
\hline DIN & 0.02 & 0.77 & 0.474 & 0.01 & 1.78 & 0.128 & 0.00 & 1.49 & 0.206 \\
\hline $\mathrm{TP}$ & 0.00 & 0.59 & 0.619 & 0.01 & 4.26 & 0.017 & 0.03 & 4.35 & 0.011 \\
\hline
\end{tabular}

\section{A}
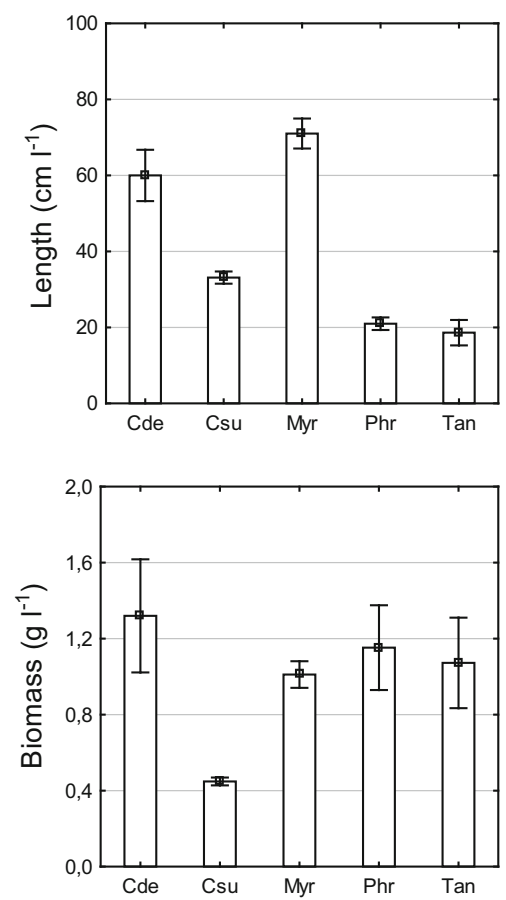

B
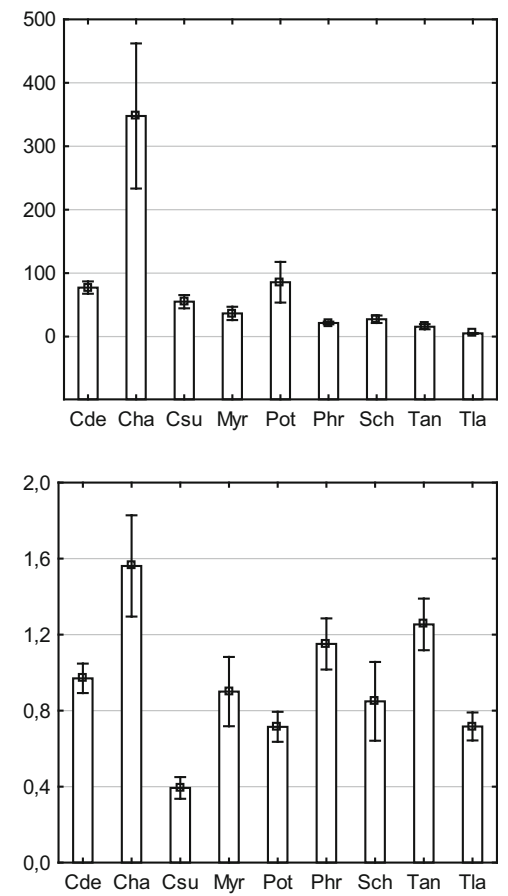

C
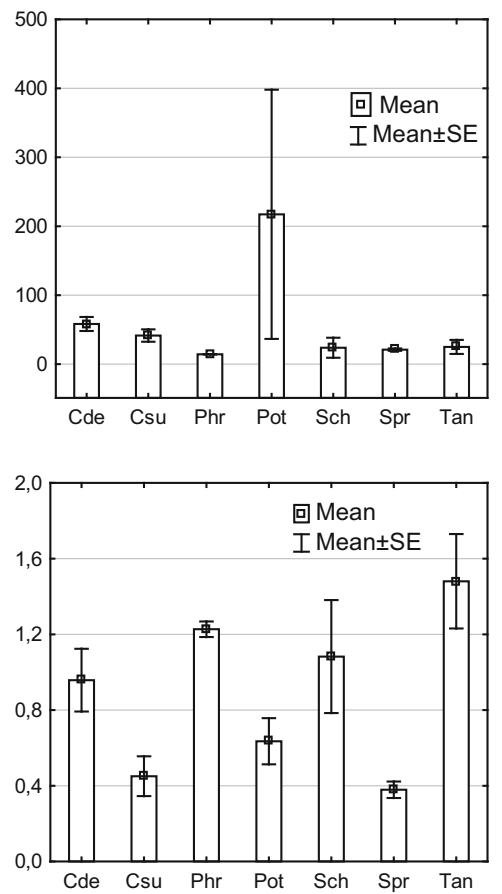

Fig. 3 Comparison of the length and biomass of macrophyte species in different trophic states of water (column A mesotrophic, B eutrophic, C hypereutrophic). Species symbols: Phr Phragmites australis, Sch Schoenoplectus lacustris, Spr

increase of biometric features in the presence of elodeids such as Myriophyllum spp., while copepod diversity was associated with the stands of $C$. demersum beds. Other macrophyte species were of minor importance in mesotrophic water bodies.
Sparganium erectum, Tan Typha angustifolia, Tla T. latifolia, Cde Ceratophyllum demersum, Csu C. submersum, Cha Chara spp., Myr Myriophyllum spp., Pot Potamogeton spp.

In eutrophic waters, parameters such as biomass of macrophytes and conductivity — water transparencyphosphorus-oxygen content were in turn important for zooplankton diversity (Table 2). Distribution of cladoceran diversity was separated from the two other 
zooplankton groups (Fig. 2) and different factors were responsible. Light availability played a key role in increasing cladoceran diversity. The remaining physical-chemical factors were generally negatively implicated with zooplankton diversity indices, especially that of rotifers and copepods. A distinctly negative relationship was found for rotifers and water mineralization. Macrophyte biometry, particularly biomass, had a decisive effect in the determination of zooplankton diversity. A significant role of charoids was found for the increase of both plant length and biomass (Fig. 1). Moreover, two helophyte species (Typha angustifolia, $P$. australis) along with elodeids ( $C$. demersum and Myriophyllum spp.) also had a definite impact on increasing biomass in eutrophic waters (Fig. 3B). The number of rotifer species and Shannon diversity index were found in close relationship with the biometric features of elodeid stands of Chara spp., Potamogeton spp. and C. demersum. Copepod diversity was mainly attributed to the presence of $T$. angustifolia stands, while cladoceran diversity rose in association with beds of Myriophyllum spp. and also T. angustifolia. The other macrophyte stands were of less importance as determinants of the diversity indices of zooplankton inhabiting eutrophic ponds.

In the hypereutrophic water bodies, besides the main environmental predictors of zooplankton diversity, distribution (biomass, OS), EC, TP and finally water transparency were also important (Table 2). Each group of zooplankton revealed a different response to environmental factors. Cladoceran diversity rose along with the increase of phosphorus content and was negatively affected by $\mathrm{pH}$ and especially by the level of oxygenation. Rotifer diversity indices were positively altered by increasing water transparency and negatively by the content of mineral substances. Plant biomass also had a strong effect in hypereutrophic waters (Fig. 1). Helophyte species (T. angustifolia, P. australis, Schoenoplectus lacustris) contributed to the biomass increase (Fig. 3C). The impact of biomass was particularly pronounced in the case of rotifers, whose diversity was highest in the presence of elodeids-two hornwort species (Ceratophyllum submersum and $C$. demersum). The highest diversity of cladocerans was attributed to the presence of helophytes ( $T$. angustifolia and S. lacustris), while copepods did not reveal any preference towards any particular macrophyte stand.

\section{Discussion}

Documentation on patterns referring to the responses of macrophyte and zooplankton metrics to trophic conditions in small water bodies is still very rare. Therefore, we highlighted zooplankton diversity measures in respect to the occurrence of plant phytocoenoses and macrophyte biometry in certain trophy stages. The discussion of these results may pose some difficulties due to the small number of studies that have been carried out on this subject so far. With the aid of the Shannon diversity index obtained for zooplankton inhabiting large water ecosystems in Russia (Habelman \& Haldna, 2014) or ponds in Belgium (De Bie et al., 2012), we demonstrated that our small water bodies were characterised by slightly higher diversity. This indicates habitat quality and regional distinctiveness (Pätzig et al., 2012). The wide range of the zooplankton diversity index in the investigated ponds reflected a high level of habitat heterogeneity. Macrophytes in ponds, which can overgrow the whole column of water or occur in patches, can be a home for a variety of zooplankters, both macrophyte-associated as well as migrating pelagic species, as stated by van Onsem et al. (2010). Thus, a great range of zooplankton diversity was also ascertained for small water bodies in an agricultural landscape.

The distribution of physical-chemical variables suggested gradients typical of certain trophic stages. Water trophy plays a crucial role in shaping zooplankton abundance dynamics (Karabin et al., 1997) or relationships between rotifers and crustaceans, leading towards a domination of small-sized rotifers. Moreover, the frequency of species typical for high trophic waters increases (Jeppesen et al., 2011). Analysing the diversity of zooplankton we observed a tendency for the highest diversity to occur in waters of lower trophic conditions. This particularly referred to crustaceans which decreased in diversity with increased trophic conditions. Rotifers, however, build richest communities in eutrophy.

Variation in nutrient concentration as well as a decrease in water transparency will affect the relationships between macrophytes and phytoplankton (Scheffer, 2001). Therefore, the occurrence and frequency of certain macrophyte species or biometric parameters may also change along with varying trophic conditions and thereby influence zooplankton 
diversity. All these observations were found to be true in the case of the examined small water bodies.

The low number of mesotrophic water bodies and the lack of oligotrophic water bodies which we observed within a large part of Poland indicates a common pattern of heavy overloading of these waters by biogenic compounds. Indicator species of zooplankton, which occur as a natural consequence of differences in the trophic status in response to nutrient supply, can highlight the importance of even a single parameter. In hypereutrophic ponds, disturbed by an excess of organic and inorganic compounds (Gałczyńska et al., 2011), TP contributed to an increase of cladoceran diversity. Hence, the interpretation of the relations biocoenosis-biotope is difficult and some environmental effects may be illusory.

A direct consequence of eutrophication is a rise in water turbidity and a decrease of light availability in water (Pieczyńska, et al., 1999; Joniak, et al., 2003). This is reflected in the macrophyte composition (with the greater impact of helophytes) and total amount of macrophyte stands, whose share in the examined sites decreased along with the trophic gradient. The impinging effect of the elimination of macrophytes on the entire hypereutrophic ecosystem is a reduction of the available microhabitats and thus the diversity of aquatic biocoenoses, including zooplankton. Such a scenario was observed in our ponds, where both rotifers and crustaceans exhibited a very low level of diversity in ponds of highest trophy.

A reflection of changes in the quality of the aquatic environment in the ascending gradient of trophy was a change in the relationship light-chlorophyll-zooplankton. In mesotrophic ponds, light availability and chlorophyll were relatively strongly related to cladoceran and rotifer diversity, while in eutrophic waters these factors affected only cladocerans. Meanwhile, in hypereutrophic ponds relations were poor, and in the case of chlorophyll reversed. The inverse relation light—chlorophyll suggests a seemingly insignificant role of light in the formation of high primary production in the subsurface layer (Joniak et al., 2003), which may be a signal of reduced control by zooplankton. Results of RDA confirmed that chlorophyll was of little importance in structuring zooplankton diversity, especially in hypereutrophy. This relationship can be decisive for community densities, while diversity is rather attributed to the architecture of a habitat and this is why we found plant biometry to be crucial in supporting zooplankton diversity, irrespective of trophic state.

Macrophytes may very promptly and markedly respond, in terms of macrophyte abundance and composition, to increased nutrient impacts in very shallow water bodies (Moss, 1990; Melzer, 1999; Lyche-Solheim et al., 2013), similarly to our ponds. Thus, RDA analysis extracted biomass of a macrophyte habitat as a factor that decisively structures the diversity of zooplankton in various trophic types of small water bodies. However, biometry is not the only important factor positively affecting zooplankton diversity. We also ascertained that in each trophic state, different macrophyte species were responsible for obtained relationships. The majority of aquatic plants occur in a broad ecological amplitude, although some species are known to be restricted to a certain trophic nature (Kłosowski, 2006), e.g. Ceratophyllum demersum. This macrophyte occurred in all trophic types of the studied ponds and it supported high zooplankton diversity. Moreover, Typha angustifolia, of a generally wide distribution, had a positive effect on the increase of cladoceran diversity in eutrophic and hypereutrophic waters. On the contrary, Myriophyllum spp. had the greatest influence on the increase of cladocerans in the case of mesotrophy and to a lesser extent in eutrophy. We also observed the effect of certain ecological groups of aquatic plants in supporting zooplankton diversity. In highly eutrophic waters, where filamentous algae may overgrow the submerged substratum, the macrophyte fitness is likely to be worse (Pokorný \& Björk, 2010). We found such a relationship in the case of biomass of elodeids, which formed stands of lower biomass along with increasing trophy. In mesotrophic ponds, only elodeid species (especially $C$. demersum and Myriophyllum spp.) supported high zooplankton diversity. However, the opposite trend was observed for helophytes (especially T. angustifolia, Phragmites australis and Schoenoplectus lacustris), whose biometry was highest in hypereutrophic waters. Moreover, only in eutrophic ponds were charoids found to positively affect the biometry of macrophytes.

Another phenomenon, related to the relationships between macrophyte biometry and zooplankton diversity indices, was connected with segregation between rotifers and cladocerans in eutrophic and hypereutrophic ponds. Cladoceran diversity was strongly influenced by helophyte biometry, particularly 
biomass of $T$. angustifolia. Such an association between cladoceran richness and helophytes, plants of less complex build than elodeids, provides additional support for the possibility of utilising emergent macrophytes as anti-predator refuges (KuczyńskaKippen \& Nagengast, 2006). Therefore, a sparse stem structure allowed cladocerans to migrate within the plant stand and along with the occurrence of littoral species it contributed to the increase in the overall diversity metrics. At the same time, rotifer diversity was positively influenced by the elodeid metrics of Chara spp., Potamogeton spp. and C. demersum in the case of eutrophy and of two hornwort species (Ceratophyllum submersum and $C$. demersum) in the case of hypereutrophy. The role of $C$. submersum in supporting rotifer diversity in high trophic waters was confirmed by Nagengast \& Kuczyńska-Kippen (2015), who considered metrics of C. submersum as an indicator of high water trophy.

In summary, it can be stated that zooplankton diversity and macrophytes can be used as tools for the assessment of water quality state in small and shallow water bodies. Segregation between rotifers and cladocerans with respect to water trophy and macrophyte biometry was observed: optimum diversity of rotifers was observed in eutrophy, while that of crustaceans was found in mesotrophy. In each trophic stage, a key predictor of zooplankton diversity was biomass of macrophytes, attributed to various ecological types or various species of macrophytes. A shift from the high importance of elodeids in structuring zooplankton diversity in mesotrophic waters to helophytes in hypereutrophic ponds was recorded. Adverse abiotic conditions, mainly caused by nutrient overloading, led to the elimination of macrophyte-dominated refuges and thus to the lowest zooplankton diversity in hypereutrophy.

Acknowledgments This research work was financed by the Polish State Committee for Scientific Research in 2010-2014 as research Project N N305 042739. The authors are thankful to Ph.D. Barbara Nagengast for identification of macrophyte species and biometric features measurements and Prof. Maciej Gąbka for statistical analyses.

Open Access This article is distributed under the terms of the Creative Commons Attribution 4.0 International License (http:// creativecommons.org/licenses/by/4.0/), which permits unrestricted use, distribution, and reproduction in any medium, provided you give appropriate credit to the original author(s) and the source, provide a link to the Creative Commons license, and indicate if changes were made.

\section{References}

APHA, 1998. Standard Methods for the Examination of Water and Wastewater, 20th ed. American Public Health Association, Washington DC.

Barnett, A. \& B. E. Beisner, 2007. Zooplankton biodiversity and lake trophic state: explanations invoking resource abundance and distribution. Ecology 88(7): 1675-1686.

Carlson, R. E., 1977. A trophic state index for lakes. Limnology and Oceanography 22: 361-369.

Carlson, R. E. \& J. Simpson, 1996. A Coordinator's Guide to Volunteer Lake Monitoring Methods. North American Lake Management Society, Madison.

Cazzanelli, M., T. P. Warming \& K. S. Christoffersen, 2008. Emergent and floating-leaved macrophytes as refuge for zooplankton in a eutrophic temperate lake without submerged vegetation. Hydrobiologia 605: 113-122.

Céréghino, R., D. Boix, H.-M. Cauchie, K. Martens \& B. Oertli, 2014. The ecological role of ponds in a changing world. Hydrobiologia 723(1): 1-6.

De Bie, T., L. De Meester, L. Brendonck, K. Martens, B. Goddeeris, D. Ercken, H. Hampel, L. Denys, L. Vanhecke, K. Van der Gucht, J. Van Wichelen, W. Vyverman \& S. Declerck, 2012. Body size and dispersal mode as key traits determining metacommunity structure of aquatic organisms. Ecology Letters 15(7): 740-747.

De Marco Jr., P., D. S. Nogueira, C. C. Correa, T. B. Vieira, K. D. Silva, N. S. Pinto, D. Bichsel, A. S. V. Hirota, R. R. S. Vieira, F. M. Carneiro, A. A. Bispo, P. Carvalho, R. P. Bastos, C. Ilg \& B. Oertli, 2014. Patterns in the organization of Cerrado pond biodiversity in Brazilian pasture landscapes. Hydrobiologia 723(1): 87-101.

Dibble, E. D. \& S. M. Thomaz, 2006. A simple method to estimate spatial complexity in aquatic plants. Brazilian Archives of Biology and Technology 49(3): 421-428.

Duggan, I. C., 2001. The ecology of periphytic rotifers. Hydrobiologia 446(447): 139-148.

Gałczyńska, M., R. Gamrat \& K. Pacewicz, 2011. Influence of different uses of the environment on chemical and physical features of small water ponds. Polish Journal of Environmental Studies 20(4): 885-894.

Habelman, J. \& M. Haldna, 2014. Indices of zooplankton community as valuable tools in assessing the trophic state and water quality of eutrophic lakes: long term study of Lake Võrtsjärv. Journal of Limnology 73(2): 263-273.

Jeppesen, E., P. Noges, T. A. Davidson, J. Haberman, T. Noges, K. Blank, T. L. Lauridsen, M. Søndergaard, C. Sayer, R. Laugaste, L. S. Johansson, R. Bjerring \& S. L. Amsinck, 2011. Zooplankton as indicators in lakes: a scientific-based plea for including zooplankton in the ecological quality assessment of lakes according to the European Water Framework Directive (WFD). Hydrobiologia 676: 279-297. 
Joniak, T., R. Gołdyn \& A. Kozak, 2003. The primary production of phytoplankton in the Maltański Reservoir in Poland. Hydrobiologia 506-509: 311-316.

Joniak, T., N. Kuczyńska-Kippen \& B. Nagengast, 2007. The role of aquatic macrophytes in microhabitatual transformation of physical-chemical features of small water bodies. Hydrobiologia 584: 101-109.

Karabin, A., J. Ejsmont-Karabin \& R. Kornatowska, 1997. Eutrophication processes in a shallow, macrophyte dominated lake - factors influencing zooplankton structure and density in Lake Łuknajno (Poland). Hydrobiologia 342-343: 401-409.

Kłosowski, S., 2006. The relationships between environmental factors and the submerged Potametea associations in lakes of north-eastern Poland. Hydrobiologia 560: 15-29.

Kłosowski, S. \& E. Jabłońska, 2009. Aquatic and swamp plant communities as indicators of habitat properties of astatic water bodies in north-eastern Poland. Limnologica 39(2): 115-127.

Kondracki, J., 2001. Regional Geography of Poland. PWN Press, Warsaw.

Kuczyńska-Kippen, N. \& B. Nagengast, 2006. The influence of the spatial structure of hydromacrophytes and differentiating habitat on the structure of rotifer and cladoceran communities. Hydrobiologia 559(1): 203-212.

Lepš, J. \& P. Šmilauer, 2003. Multivariate Analysis of Ecological Data Using CANOCO. Cambridge University Press, Cambridge.

Lyche-Solheim, A., C. K. Feld, S. Birk, G. Phillips, L. Carvalho, G. Morabito, U. Mischke, N. Willby, M. Søndergaard, S. Hellsten, A. Kolada, M. Mjelde, J. Böhmer, O. Miller, M. T. Pusch, C. Argillier, E. Jeppesen, T. L. Lauridsen \& S. Poikane, 2013. Ecological status assessment of European lakes: a comparison of metrics for phytoplankton, macrophytes, benthic invertebrates and fish. Hydrobiologia 704: 57-74.

Mack, H. R., J. D. Conroy, K. A. Blocksom, R. A. Stein \& S. A. Ludsin, 2012. A comparative analysis of zooplankton field collection and sample enumeration methods. Limnology and Oceanography: Methods 10(1): 41-53.

Malthus, T. J., E. P. H. Best \& A. G. Dekker, 1990. An assessment of the importance of emergent and floatingleaved macrophytes to trophic status in the Loosdrecht lakes (The Netherlands). Hydrobiologia 191: 257-263.

Margalef, R., 1957. Information theory in ecology. General Systems 3: 36-71.

McAbendroth, L., P. M. Ramsay, A. Foggo, S. D. Rundle \& D. T. Bilton, 2005. Does macrophyte fractal complexity drive invertebrate diversity biomass and body size distribution. Oikos 111(2): 279-290.

Melzer, A., 1999. Aquatic macrophytes as tools for lake management. Hydrobiologia 395: 181-190.

Moss, B., 1990. Engineering and biological approaches to the restoration from eutrophication of shallow lakes in which aquatic plant communities are important components. Hydrobiologia 200(201): 367-377.

Nagengast, B. \& N. Kuczyńska-Kippen, 2015. Macrophyte biometric features as an indicator of the trophic status of small water bodies. Oceanological and Hydrobiological Studies 44(1): 38-50.

Obertegger, U. \& M. Manca, 2011. Response of rotifer functional groups to changing trophic state and crustacean community. Journal of Limnology 70(2): 231-238.

Pätzig, M., T. Kalettka, M. Glemnitz \& G. Berger, 2012. What governs macrophyte species richness in kettle hole types? A case study from Northeast Germany. Limnologica 42: 340-354.

Pieczyńska, E., A. Kołodziejczyk \& J. I. Rybak, 1999. The responses of littoral invertebrates to eutrophication-linked changes in plant communities. Hydrobiologia 391: 9-21.

Pokorný, J. \& S. Björk, 2010. Development of Aquatic Macrophytes in Shallow Lakes and Ponds. In Eiseltová, M. (ed.), Restoration of Lakes, Streams, Floodplains, and Bogs in Europe: Principles and Case Studies, Wetlands: Ecology, Conservation and Management 3. Springer Science+Business Media B.V.: 37-43.

Roman, C. T., N. E. Barrett \& J. W. Portnoy, 2001. Aquatic vegetation and trophic condition of Cape Cod (Massachusetts, U.S.A.) kettle ponds. Hydrobiologia 443(1-3): 31-42.

Scheffer, M., 2001. Alternative attractors of shallow lakes. The Scientific World 1: 254-263.

Schriver, P. J., E. Bøgestrand, E. Jeppesen \& M. Søndergaard, 1995. Impact of submerged macrophytes on fish-zooplankton-phytoplankton interactions: large scale enclosure experiments in a shallow eutrophic lake. Freshwater Biology 33: 255-270.

Stansfield, J. H., M. R. Perrow, L. D. Tench, A. J. D. Jowitt \& A. A. L. Taylor, 1997. Submerged macrophytes as refuges for grazing Cladocera against fish predation: observations on seasonal changes in relation to macrophyte cover and predation pressure. Hydrobiologia 342(343): 229-240.

ter Braak, C. J. F. \& P. Šmilauer, 2002. CANOCO Reference Manual and CanoDraw for Windows User's Guide: Software for Canonical Community Ordination (Version 4.5). Microcomputer Power, Ithaca.

Tolonen, K. T., H. Hämäläinen, I. J. Holopainen, K. Mikkonen \& J. Karjalainen, 2003. Body size and substrate association of littoral insects in relation to vegetation structure. Hydrobiologia 499(1-3): 179-190.

Van Onsem, S., S. De Backer \& L. Triest, 2010. Microhabitatzooplankton relationship in extensive macrophyte vegetations of eutrophic clear-water ponds. Hydrobiologia 656(1): 67-81.

Wojtal, A., P. Frankiewicz, K. Izydorczyk \& M. Zalewski, 2003. Horizontal migration of zooplankton in a littoral zone of the lowland Sulejow Reservoir (Central Poland). Hydrobiologia 506(509): 339-346.

Zervoudaki, S., T. G. Nielsen \& J. Carstensen, 2009. Seasonal succession and composition of the zooplankton community along an eutrophication and salinity gradient exemplified by Danish waters. Journal of Plankton Research 31(12): 1475-1492. 